\title{
Crop Production, Gender Roles and the Use of Mobile Phones and Radios for Agricultural Information by Farmers in Apac District, Northern Uganda
}

\author{
David Mugambe Mpiima1 ${ }^{*}$, Henry Manyire1, Consolata Kabonesa1, Margareta Espiling² \\ ${ }^{1}$ School of Women and Gender Studies, Makerere University, Kampala, Uganda \\ ${ }^{2}$ Department of Economy and Society, Gothenburg University, Gothenburg, Sweden \\ Email: ^davidmpiima@gmail.com
}

How to cite this paper: Mpiima, D.M., Manyire, H., Kabonesa, C. and Espiling, M. (2019) Crop Production, Gender Roles and the Use of Mobile Phones and Radios for Agricultural Information by Farmers in Apac District, Northern Uganda. Open Journal of Social Sciences, 7, 89-111. https://doi.org/10.4236/jss.2019.73007

Received: January 4, 2019

Accepted: March 5, 2019

Published: March 8, 2019

Copyright (๑) 2019 by author(s) and Scientific Research Publishing Inc. This work is licensed under the Creative Commons Attribution International License (CC BY 4.0).

http://creativecommons.org/licenses/by/4.0/

\begin{abstract}
The introduction of information communication technologies like mobile phones and radios as a form of agricultural extension has the capacity to alter household gender roles. The information access that was previously more available to men than women, has the capacity to empower farmers by improving their ability to turn food crops into market oriented crops. This implies that food crops, previously seen as women's crops, also become cash crops, which were thought to be men's crops. This change also leads to changes in agricultural gender roles. The anticipated increase in agricultural productivity also leads to men or hired labour participating in agricultural roles that were previously thought to be women's roles, so as to meet the market demands in a timely manner. The dual purpose of the crops leads to more joint labour provision along the agricultural production process and blurs the gender divide. The study used a sequentially mixed methods' approach among farmers belonging to five farmer groups in Apac district in Northern Uganda. The study indicated that the use of mobile phones in agricultural production altered agricultural gender roles, as well as the participation of women and men in the production of food crops and cash crops. The changes greatly benefited women farmers as they moved into commercial production alongside their husbands, which changed their socio-economic status. The use of mobile phones and radios is important in fostering the participation of both men and women in agricultural roles that they previously did not engage in, since there is limited monopoly of information once a couple navigates issues of power relations surrounding the access to and use of the technologies.
\end{abstract}




\section{Keywords}

Information and Communication Technologies, Agricultural Information, Gender Relations

\section{Background}

Gender, as a powerful ideological tool, produces and reproduces roles performed by both men and women in different structures making social change either possible or impossible [1]. Household institutional arrangements in form of gender roles respond to this order and it is in this light that male dominance and women's double day are understood [2] [3]. Whereas women can play similar roles as men in crop farming [4], there are gender differences in the roles and the crops grown by the farmers, especially for more capitalised farms [5]. Historically, men cleared land and irrigated the crops in farming communities, while women harvested, processed products, stored seeds and plants, and also selected seeds for the next season [6]. In India, among in Ashta and Umra areas, women undertake cleaning, weeding, layout preparations, application of manure, threshing as well as cleaning grain among others, while men do sowing, chemical fertilizers, irrigation, plant protection and harvesting [7]. Some crop production roles like planting and harvesting are shared in the same communities and cut across gender asymmetries because they are labor intensive [6], [5] and women also participate in post harvest activities [8]. Interdependence is thus a fact of life in crop production [5].

Other gender asymmetries are visible in crop gender relationships. In the Bangladesh, Himalayas among the Manang, women prefer wheat to barley, since barley requires more strength as it is firmly attached to the straws, but its threshing is done by men and hired labor [4]. In some communities in Northern Kenya, eventually, all crops are sold by the women who grow them e.g. bananas, mangoes, oranges, tomatoes, etc. [5]. In India, among the Ashta and Umra areas, crops like rice, wheat and maize are the biggest domestic crops and are preferred by women, while groundnuts, soybeans and legumes, as well as vegetables are mostly men crops, since they add to household income [7]. However, this mechanistic dichotomy of cash crops being men's crops and food crops being women's crops is more fluid than most writers recognize [9].

The cash crop food crop dichotomy can also be reduced by new technology, moving women from "women's" crops to "men's" crops by getting them into marketing roles [10]. However, this may come at the cost of women's time as an increase in participation in cash crops will mean that women spend even more total time in agriculture, while men may end up spending less [11]. Women end up doing more weeding due to the application of fertilizers and spend more time in processing of the increased yield. However, as their total time in agricultural production increases, their income, control and independence are likely to in- 
crease as well.

On the other hand, Information Communication Technologies (ICTs) such as mobile phones and radios are used to provide agricultural information to farmers. The application of such agricultural information has the ability to change men and women's agricultural roles and social networks [10]. ICTs can also improve women's traditional roles like in the case of the Bolivian women. These women used mobile phones in their marketing function, but the phones only affected their marketing decisions and caused marketing improvements in a role they have performed for a very long time [12]. Technology may also affect the post-harvest activities if farmers choose to invest in improved storage mechanisms or mills to free their labor-time based on information acquired about post-harvest handling [10].

In Africa, especially in the rural areas, there is increasing evidence now of an increase in access to and use of ICTs like mobile phones and radios to support the traditional extension system [13]. This is evident in countries like Cote d'Ivoire, Ghana, Nigeria, Mali, Rwanda, Tanzania, Zambia, Mozambique, Malawi, and Madagascar [14]. The introduction of such ICTs, interacts with dynamic gender roles in the complex and heterogeneous African households, implying gendered impacts on men and women farmers [10]. Given that ICTs aim to shift African farmers away from weather dependent subsistence to commercial farming, the impact on gender roles is likely to be enormous [15].

In Uganda, like other countries in the global south, ICTs like mobile phones and radios have been promoted by both government and civil society organizations (CSOs) as a solution to the inadequate agricultural extension services. The gender relations around agricultural production indicate that women constitute $77 \%$ of the agricultural labor force in a sector that employs $72 \%$ of Ugandans though few participate in the marketing function of the sector, as it is men dominated [16]. Ninety percent of rural Ugandans are active in the sector [17]. Being a country with patriarchal social organization, men control agricultural land as well as resource allocation in the households, including technologies like mobile phones and radios [18] [19]. Women with mobile phones in Uganda, are more likely to use them for agricultural information than men, and women use them to support collective farming groups [18] [20] [21]. The ultimate aim of promoting the use of ICTs is to move men and women farmers from subsistence production to commercial production [22]-[27].

In Eastern Uganda, particularly in the Busoga region, commercialization of agriculture in the early 1990s blurred the gender asymmetries with formerly food crops like cassava, millet, groundnuts, maize, beans, matooke and sim sim joining the list of cash crops like coffee and cotton [8]. The same change was witnessed in Teso in Eastern Uganda according to a study carried out [28]. Cropping diversified overtime and cassava overtook millet in importance, and rice emerged as an alternative crop as cotton growing collapsed. However, this change altered the gender roles, by allowing women more room for maneuver, since they were no longer solely responsible for food production [8]. Men thus 
got more involved and took over food production. The change created more negotiated gender relationships with food and cash crops playing complementary roles. Needless to say, this complementarity never morphed into equal control over resources between wife and husband. The husband had greater control even when wives could run independent cotton plots. Women used to bargain from an even weaker position after losing control over "their crops", the food crops.

In Apac district, the site of the study that informs this paper, society has traditionally been organized along patriarchal lines where women are historically subordinate to men with explicit responsibilities [29]. Gender relations were thus organized in favor of men as the dominant category that also controlled land as a productive resource [30], made family decisions on incomes, while women were responsible for domestic tasks like cooking, fetching water, and washing [31]. It is on this land that the Langi in Apac adopted an agro-pastoral livelihood, keeping poultry and animals like cattle, pigs, rabbits and goats, well as crops like millet, sorghum, cassava, sesame, beans, groundnuts, maize, sweet potatoes, sunflower, and soybeans [32]. Agricultural production gender roles like land preparation, planting and weeding were jointly done by men and women, while women harvested most crops and handled post-harvest activities through colonialism and modern times [32]. Women had some limited control over small garden plots and some few crops [30] [31]. Therefore, both men and women had explicit roles and responsibilities even when the society was mostly engaged in subsistence production [29] [33]. Other forms of labor included Wang tic (reciprocal labor) that involved both men and women [33] and polygamy was also viewed as a source of labor where the many wives and their children would offer free labor on the man's land [34].

The gendered organization of both land and labor changed during colonialism as the Langi men were forced to engage in cash crop production of mainly cotton and tobacco to be able to pay hut tax [19]. Women, on the other hand, became more of labor suppliers to both food crops and cash crops. Further changes to gender relations took place during the two decades long Lord's Resistance Army (LRA) insurgency that herded most people in Northern Uganda including those in Apac, into internally displaced people's camps (IDPs) [31] [35]. IDP camps altered gender relations so much that men were disempowered, lost their authority and started taking on casual agricultural jobs, like women [31]. Women, on the other hand, maintained their gender roles, but also took on new commercially viable roles in the labor market as casual laborers [35]. The war thus severally challenged masculine power in the region.

After the war ended, further changes took place, including resettlement from IDPs camps, reintroduction of men into both labor and household authority in rapidly changing socio-economic circumstances [35]. Having officially seen the end of the war in 2008, agricultural activities are thriving once again, having doubled to $112 \%$ in recent years [32]. New crops, especially fruits like oranges and passion fruits, have also been introduced [36]. The division between cash crops and food crops has been blurred as both crops serve a dual cash and food 
purpose [19] [37].

The introduction of ICTs in early 2003 as the war scaled down [38] is another of the biggest changes for farmers in Apac district. Despite the many changes that were taking place, agricultural production was unchanging as old problems that dogged farmers like low/fluctuating prices, lack of transport, lack of agricultural information, lack of storage facilities and post harvest technologies as well as inefficient extension services still existed [39]. Farmers started using ICTs to overcome some of these perennial agricultural production challenges. It had become apparent that improvements in access to inputs, interaction with traders, increase in productivity, and access to markets had to be information enabled for both men and women farmers to benefit [14]. However, the impact of the use of ICTs like mobile phones and radios for agricultural information on gender roles has not been well documented. The interest of this study was nevertheless in the gender related changes that take place the gender roles performed by men and women as well as the changes in the production of food and cash crops.

\section{Theoretical Background}

The paper uses empowerment as a theoretical anchor. Empowerment is the capacity to make strategic and meaningful choices by those who have previously been denied this capacity, but in ways that do not merely reproduce, but indeed actively challenge the structures of inequality in their society [40]. The aim is to enable those previously denied the ability to make strategic life choices to acquire such ability to inspire collective action and decision-making [40] [41]. Empowerment is a social rather than an individual process of change in the family, community, market and state arenas that transforms power relations [40] [42] [43]. The process of change is geared towards changing gender relations by building critical consciousness [43]. In terms of agricultural information needs, technological access addresses informational needs, making access to information a powerful resource in its own right that is buttressed by the old cliché "knowledge is power" [44]. This knowledge essentially enables women, as individuals or in groups, to challenge existing power structures and relations that subordinate them in a bottom-up strategy, to question oppression and deprivation, to have influence and to be heard [13] [45] [46]. The aim is to bridge gender power relations and enable those previously denied the ability to make strategic life choices to acquire such ability [43]. The necessity for empowerment is because development interventions have the ability to bypass women because of patriarchy and the exploitation of anything feminine, including nature and women alike [47]. Thus empowerment is both a process and an outcome that is relational, intimate and personal in nature and aims at changing gender power relations at a personal or group level [41] [48]. It is dynamic and provisional, with nuanced negotiations, accommodation and compromise [49]. It is these subtle negotiations that determine which resources are accessed, the gender roles 
performed, and achievements realized or not. The introduction of mobile phones and radios, and the knowledge acquired from using these ICTs, therefore, may lead to alteration of gender relations and gender roles in agricultural production [47].

\section{Research Design and Research Procedure}

The study used a sequentially mixed methods approach, starting with the quantitative method, which was followed by qualitative methods. The study initially employed the survey design to collect quantitative data. Data was collected from 34 men and 95 women farmers belonging to five farmer groups namely, Bed Igen women farmers group, Ibabang Kwo women farmers group, Oribcan women farmers group, Obanga Atwero Mot Mot Atwero women farmers group and Gen Rwot women farmers group located in Akokoro Sub County and Apac Municipality in Apac district. Members of these farmer groups used both mobile phones and radios for agricultural production information. Quantitative data were analyzed using the statistical package for social scientists (SPSS). This analysis was used to generate statistical data. The gaps and issues that were identified in quantitative data were addressed using quantitative methods of data collection including; focus group discussions, observations and key informants interviews. Focus group discussion (FGD) guides, observation guides and key informant interview guides, were designed and used in this phase. The qualitative data were thematically analyzed in such a way that brings out the voices that depict household gender roles. The integration of the quantitative and qualitative findings gave rise to the presentation below.

\section{Presentation of Findings}

The commonest crops grown among the framer groups in Apac District included; beans, sunflower, cassava, millet, sweat potatoes, bananas, maize, sorghum and sim sim. With the exception of sorghum and sunflower, the other seven crops were traditional crops in the area. Even then, sorghum was not a widely grown crop compared to the other crops. Findings showed that there were changes in the growing of sorghum, and sunflower. Thirteen women farmers had started growing sorghum after they started using mobile phones and radios. A further 13 women farmers had also taken on the growth of sim sim out of 65 women farmers that were growing the crop. Fifteen women farmers out of 81 women farmers growing maize had started growing the crop after they started using mobile phones and radios. The biggest change in terms of crops grown by both men and women farmers was in the growth of sunflower. Out of the 21 men farmers growing the crop, nine had started growing the crop after they started using mobile phones and radios. In the same breadth, 35 women farmers out of a total of 59 women farmers, started growing sunflower after they started using mobile phones and radios.

For traditional food crops like beans, maize, sweet potatoes, millet and cassa- 
va, findings showed that the changes were minimal. For crops like cassava and maize, qualitative data indicated that there was a deliberate effort from the district authorities to grow both crops as a food security measure in view of the prolonged droughts, as well as to boost household incomes.

We are encouraging the production of maize and cassava for commercial purposes. Whereas we are also giving the farmers citrus, mangoes and coffee for planting, our main efforts are with maize and cassava and we have put a lot of efforts in the second season. Here, it is better than the first season. As you can see, they have come to pick planting materials for cassava and maize alongside other crops. We distribute to farmer groups ${ }^{1}$ having started with 12 in March 2017. By estimation, 50 percent of the group members have mobile phones, which make communication even better. (Key informant interview with the District Production Officer, March 2018.)

The process of selecting the crops was deliberate and according to the coordinator of Operation Wealth Creation (OWC) in Apac district, committees comprising of 13 members were formed to select crops that the farmers preferred. Usually, traditional crops such as maize and cassava, as well as new ones like sunflower, were selected by the committees. After the selection of the preferred crops, seedlings or cuttings were then distributed to the different farmer groups through the district office. Each household was encouraged by the district leadership to at least have one acre of maize on top of any other crop they choose to grow in a season. It emerged from the qualitative interviews that all the crops grown, except sunflower, served a dual purpose of providing food for households as well as income.

\subsection{Major Gender Roles in Crop Production}

The presentation here is made based on the chain of major agricultural activities that take place from conceiving the idea to start farming until the time a crop is sold or readied for the next planting season. The labor provision of respondents and their household members was assessed before and after they started using both mobile phones and radios. The percentages presented here go beyond $100 \%$ in some instances because of multiple responses. The number of respondents varies for the same activity, since some started doing the activity after they started using mobile phones and radios and not before, while others dropped off.

\subsubsection{Clearing of Land}

The first activity in this case was clearing of land (lweero poto'). Before the use of mobile phones and radios, a majority of the 32 men farmers $(62.5 \%)$ said they would personally clear the land, followed by $40.4 \%$ who said they would actually do this with their wives and children. Only 6.3\% used hired labor. On the side of

${ }^{1}$ These women farmer groups (now 24) included just 2 of the 5 farmer groups visited. The rest were mostly new to farming having been formed after March 2017, when the Production Officer returned from a two-week gender training from Meru, Kenya where he learnt the advantages of women's groups in agriculture and replicated in Apac District. 
the 90 women farmers, $36.2 \%$ said that clearing of agricultural land was predominantly done by the husbands, followed by $22.2 \%$ who said that they do the clearing themselves. The wife, husband and children were also mentioned to jointly offer labor to clear land by $31.1 \%$. Those who used hired labor were $7.8 \%$. After the use of mobile phones and radios, there was a $15.6 \%$ reduction in the percentage of men farmers saying that they personally cleared the land to $46.9 \%$, while those that said that it was a joint effort of the husband, wife and children, increased to $43.9 \%$. The percentage of men farmers who said that they used hired labor also increased to $15.6 \%$, while those that cited farmer groups as a source of labor, were $3.1 \%$. For the women farmers, $45.4 \%$ said that it is a joint effort between the husbands, a $14 \%$ increase; wife and children, followed by those that said that it was their husbands (18.9\%) or hired labor (18.9\%). A further $17.7 \%$ said that they personally cleared the land, with $3.3 \%$ saying that farmer groups assisted them.

\subsubsection{Acquisition of Agricultural Information}

In terms of acquisition of agricultural information, $75 \%$ of the 32 men farmers said that they used to personally access the information themselves, while $21.9 \%$ said that both the husband and wife accessed agricultural information before the use of mobile phones and radios. Thirty three percent of the 85 women farmers said that it was their husbands that used to access agricultural information before they started using mobile phones and radios. This was followed by $30.7 \%$ of the women farmers that said that agricultural information used to be jointly accessed by the husband, wife and children. A further $29.5 \%$ of the women farmers said that they had been personally accessing the agricultural information. After the use of ICTs, the percentage of men farmers saying that they were personally accessing agricultural information had reduced to $66.7 \%$, from the initial $75 \%$. However, joint access to agricultural information by the wife, husband and children had almost remained the same at $30.3 \%$. On the other hand, the percentage of women farmers saying that they had joint access to agricultural information with husbands and children had shot up to $51.7 \%$, a $21 \%$ change, while those that said that they now personally controlled access to agricultural information had remained almost the same at $30.8 \%$.

\subsubsection{Acquisition of Agricultural Inputs}

Before the use of mobile phone and radios, most of the 31 men farmers (77.4\%) would get the inputs by themselves, while $21.5 \%$ said that inputs used to be jointly secured by the husband, wife, and children. On the other hand, $39.8 \%$ of the 90 women farmers said that their husbands used to acquire agricultural information before they started using mobile phones and radios. This was followed by $31.5 \%$ who said that it was a joint effort by the husband, wife, and children, while $29.6 \%$ said that they personally used to acquire the agricultural information. For the 32 men farmers, a majority (75\%) was still personally acquiring agricultural inputs after the use of mobile phones and radios, while $25.1 \%$ said it 
was a joint effort by the husband, wife, and children. On the other hand, the percentage of the 90 women farmers that were personally accessing agricultural information had gone up to $35.6 \%$ from $29.6 \%$ after they started using mobile phone and radios. The percentage of women farmers that said that acquisition of agricultural inputs was a joint effort by the husband, wife, and children, had also increased to $37.5 \%$. There was however a reduction in the percentage of women farmers who said that their husbands were the ones accessing agricultural information to $22.2 \%$, a $17.6 \%$ reduction.

Findings further revealed that before choosing to adopt mobile phones and radios, $29.2 \%$ of the 24 men farmers who responded to this question would buy their inputs like seed, fertilizers and pesticides from their village, followed by those that would travel a distance of over $6 \mathrm{~km}(25 \%)$ and then those that would cover $3-6 \mathrm{~km}$ (20\%). On the other hand, 32.7\% of the 55 women farmers used to access inputs from home, followed by those $(25.5 \%)$ that would get inputs at a distance of between $3-6 \mathrm{~km}$ and those (18.2\%) that used to cover above $6 \mathrm{~km}$. After the introduction of mobile phones and radios for agricultural production, the number of men farmers accessing inputs from around their villages or homes, increased by $9.3 \%$ to $38.5 \%$ from $29.2 \%$, because they could now make phone calls and get the inputs. There were negligible changes amongst the other distances. Among the 55 women who responded to this question, findings revealed an eight percent increase among those that accessed the inputs from home or around the village, from $32.7 \%$ to $40 \%$. For the first time, $21.8 \%$ said that they were getting inputs from less than a kilometer from home. Findings showed a 7\% drop amongst women farmers that covered $3-6 \mathrm{~km}$ from $25.5 \%$ to $18.2 \%$. There was also a $6 \%$ drop among women farmers that covered over $6 \mathrm{~km}$ to secure inputs from $18.2 \%$ to $12.7 \%$. These changes, especially the reductions in distances covered to secure agricultural inputs, were possible because of the use of mobile phones and radios where a farmer could call and inputs are delivered to their home or through the farmer groups. The Sub County administrations too had disseminated information on radios stations about the availability of seeds, which reduced travelled distances. A woman farmer from Oribcan women's farmer group illustrated this by saying that;

Before, getting inputs was a bit difficult. There were few shops and sometimes we had to move up to town yet transport here is also very tricky. However, we now just send information to the traders when ready and they send to us in the comfort of our home. We can use mobile money to pay them. Remember the going prices of inputs are always disseminated on radios so it is hard to cheat us even from home.

\subsubsection{Preparation of Land}

A majority of the 32 men farmer respondents (69.7\%) said that preparation of land ("tongo poto") was a joint activity between the husband, wife, and children, while $28.1 \%$ said that they used to prepare the land themselves before they started using mobile phones and radios. A majority of the 88 women farmers 
(57.9\%) said that it was a joint effort of the husband, wife, and children to clear land followed by $21.6 \%$ who said that it was the husband. A further $18.2 \%$ of the women farmers said that they cleared the land themselves. After the use of mobile phones and radios, the study revealed that out of the 33 men farmers that answered, 69.6\% said that it was a joint effort between husband, wife, and children to clear land. The percentage had remained the same. However, the percentage of those saying that they had personally prepared the land, had reduced to $15.2 \%$ from $28.1 \%$, while $12.1 \%$ had introduced hired labor to help prepare the land, which they had not mentioned earlier. On the other hand, the percentage of women farmers saying that preparation of land was a joint effort had increased, from $57.9 \%$ to $65.5 \%$ out of 90 women farmers that participated in the activity after the use of mobile phones and radios. Furthermore, the percentage of women farmers using hired labor had doubled to $12.2 \%$, from $6 \%$. The percentage of women farmers that reported that they personally prepared the land was $20 \%$, a small $2 \%$ change.

Qualitative information from FGDs revealed that the changes in the labor provision in preparation of land for planting were also aided by the introduction of ox-ploughs. Many farmers had adopted this technology and those who had ploughing units would rent them out to those who did not have bulls or ploughs. The presence of the new preparation method was encouraged on radios, and it was emphasized that both men and women farmers could control the bulls and use them to ease the preparation of their land, be able to cultivate a bigger piece of land and be in time for the planting season.

When it comes to ox ploughing, it was thought that only men could do this kind of work but these days, women help the men. We take turns in controlling the oxen especially when one person is tired. We even bring the ploughs and the oxen from the gardens. We just hear about groups receiving ploughs and seedlings from the government but we just buy everything we use. We do not even hear information about the distribution of seedlings over the radios. Maybe those people just get direct calls to receive the agricultural inputs but for us they just tell us lies. The political party group you belong to also matters in these things. Those of us who support the Uganda People's Congress are never considered. (Voices from the women farmers' FGD, Bed Igen women farmer group, March 2018.)

The sentiment about not properly disseminating information for all groups through radios was because Bed Igen members were known as Uganda People's Congress (UPC) supporters, an opposition party, and thus missed out on many NRM government opportunities. However, members of Gen Rwot women farmers' group had received an ox plough and a member of the same group had also received an improved hybrid cow from the district administration.

\subsubsection{Sowing}

Most of the 32 men farmers (43.1\%) said that sowing used to be done through joint effort of the husband, wife, and children before the use of mobile phones 
and radios, followed by $27.5 \%$ who said that they would personally sow seeds, while $12.5 \%$ said it was the wife. About $9.4 \%$ said that they used hired labor for the activity. Fifty-five percent of the 89 women farmers on the other hand, said that sowing was a joint effort by husband, wife, and children, followed by $32.2 \%$, who said that it was a joint effort of the husband and wife, minus the children. About $11.2 \%$ said that their husbands did the sowing, while a further $6.7 \%$ used hired labor. After the 33 men farmers started using mobile phones and radios for agricultural information, an $11 \%$ increase was registered among those that said that sowing was a joint activity by the husband, wife, and children, to $54.6 \%$. The percentage contribution of the wife also increased to $21.2 \%$, from $12.5 \%$. There was however a $6 \%$ reduction in the percentage of men farmers that said that they personally used to do the sowing, down to $21.2 \%$. The percentage of men farmers using hired labor also reduced from $9.4 \%$, to $6.1 \%$. On the other side of the 88 women farmers, there was a small increase in the percentage saying that they were personally sowing their seeds, to $58 \%$ from $55.1 \%$. There was also another increase in the percentage of women farmers that said that sowing was a joint effort between husband, wife, and children from $32.2 \%$ to $38.6 \%$. The share of women farmers that said that it was their husbands that used to sow dropped to a mere $2.3 \%$ from $11.2 \%$, while hired labor remained $6.8 \%$.

\subsubsection{Weeding}

A majority of the 32 men farmers (59.4\%) said that weeding was a joint effort between husband, wife, and children before they started using mobile phones and radios, followed by those that said that it was the wife at $28.1 \%$. Hired labor and personally getting involved in weeding were both mentioned by $9.4 \%$ of the men farmers respectively. Of the 90 women farmers, $46.7 \%$ were doing the weeding themselves; while $45.8 \%$ said it was a joint effort between husband, wife and children. Ten percent reported that they were using hired labor to weed their crops. After they started using mobile phones and radios, the study revealed that there was a $10 \%$ increase in the percentage of men farmers using joint labor to weed to $68.9 \%$. Hired labor had slightly increased from $9.4 \%$ to $15.6 \%$. The contribution of wives in weeding reduced from $28.1 \%$ to $18.8 \%$. Among the women farmers, there was also an increase in joint labor in weeding. The percentage of women farmers saying that they were using joint labor had shot up to $53.3 \%$ from $45.8 \%$. There was however a reduction among women farmers saying that they personally did the weeding, to $40 \%$, from $46 \%$. Hired labor increased slightly from $10 \%$ to $13.3 \%$.

\subsubsection{Harvesting}

Of the 31 men farmers, most of them (83.9\%) said that the labor for harvesting was jointly offered by the husband, wife, and children before the use of mobile phones and radios, followed by harvesting themselves. On the other hand, out of the 88 women farmers, $64.7 \%$ said that they jointly harvested with their husbands and children, followed by $27.3 \%$ who said that they did the harvesting 
themselves. Farmer groups were mentioned by $13.4 \%$ of the women farmers as a source of harvesting labor, and $8 \%$ said that they used hired labor. After the use of mobile phones and radios, the number of men farmers saying that they use joint labor in harvesting with wives and children increased by $7 \%$, to $90.6 \%$. In one of the interviews, a man said;

I noticed that we were harvesting more than before and at times, you need money quickly so I participate more alongside my wife in harvesting work. (Interview with a man farmer, Oribcan women farmers' group, March 2017.)

There were however negligible changes for women farmers in harvesting work after they started using mobile phones and radios for agricultural production.

\subsubsection{Transportation from Garden}

A majority of the 32 men farmers (71.9\%) said that transportation of produce from the garden was through joint labor of the husband, wife, and children before the use of mobile phones and radios for agricultural information. A further $18.2 \%$ said that they personally used to transport their produce from the garden, while $3.1 \%$ used hired labor. On their part, 55.6\% of the 90 women farmers said that they were using joint labor of with husband and children, followed by $21.2 \%$ who were transporting produce by themselves, while $18.9 \%$ said it was their husbands doing it. A further $10 \%$ were using hired labor.

Mothers used to transport foodstuffs and fathers would take a big share of the transportation burden of cashcrops. Nowadays, women almost sell anything from the garden and men too have changed because of the information on radios and in the trainings in our groups. Men allow their women to move unlike in the past. (Interview with a man farmer, Oribcan women farmers group, March 2017.)

After they started using mobile phones and radios, the percentage of men farmers using hired labor went up to $15 \%$, from $3.1 \%$. On their part, women farmers reporting that they were using shared labor alongside their husbands and children shot up to $67.9 \%$, from $55.6 \%$. There was however a $5 \%$ reduction among women farmers who had said that they personally transported their produce, from $21.2 \%$ to $16.6 \%$.

\subsubsection{Winnowing}

A majority of the 32 men farmers $(78.1 \%)$ said that their wives did winnowing (diinu) before they started using mobile phones and radios in agricultural production. A further $9.4 \%$ of the men farmers said that winnowing was done using hired labor. In addition, $6.3 \%$ of the men farmers said that they did the winnowing. Those who said that it was a joint effort of the husband and wife, as well as those saying that winnowing was done by in-laws were $3.1 \%$ a piece. The majority of the 90 women farmers $(91.1 \%)$ said that they personally used to winnow their produce before they started using mobile phones and radios, while $5.5 \%$ said it was a joint activity between them and their girl-children. The use of hired labor was mentioned by $2.2 \%$ of the women farmers. After the use of mobile 
phones and radios, there was a 6\% drop in the percentage of men farmers whose wives were doing winnowing to $72.7 \%$ out of the 33 men that responded. There were also increases in the percentage of men farmers who were jointly doing winnowing to $12.1 \%$ from $6.3 \%$, as well as those that personally did the winnowing.

I have just been winnowing, am sure you have seen for yourselves. You cannot wait for the wife to do that when the harvest is that big, you may never sell on time. (Interview with a man farmer, Oribcan women farmers group, March 2017.)

In relation to the women farmers, there was a drop among those that were personally doing the winnowing to $84.4 \%$ from $91.1 \%$, while $6.6 \%$ said that they did the winnowing with their girl-children.

Winnowing was traditionally a feminine role among the Langi and this explains why women farmers and their daughters mostly did it. There are different types of winnowing as explained by the farmers in the FDGs. The first type of winnowing was kwooro, which is wind aided winnowing. This was where some few men farmers participated. The second type of winnowing pyeto, was manual winnowing. Here, one uses an odero to winnow and blows air using his/her mouth during the process. Odero was a locally woven tray/basket used for winnowing. The basket is smeared with cow dung and left to dry to keep pests away. The odero are made and used by only women, which implies that only women do pyeto. The third type of winnowing was yeko. It was usually employed in the winnowing of groundnuts and beans. Chaff is separated from the grains during this process. Only women participated in this. Wood and wire mesh were used to make the required tool to be used during this process. The small number of men farmers in winnowing was attributed to the tedious work involved and the shame attached to the activity in the Langi culture since it is tagged with the feminine identity or theft.

Most of the men still do not like winnowing because they feel ashamed and it is also very hard. The culture here discourages men from winnowing because it is assumed that the men who participate in winnowing want to steal the women's produce and sell it off. They are thus seen as greedy men and no one wants that tag. (Women voices from a mixed FGD, Gen Rwot women farmers', March 2018.)

\subsubsection{Sorting}

Most of the 32 men farmers (65.6\%) reported that their wives did the sorting before they started using mobile phones and radios, followed by $12.5 \%$ who said that it was a joint effort of the husband and wife. A further $12.5 \%$ said that they used to sort the produce themselves, while $6.3 \%$ said that, they used to use hired labor. The majority of the 90 women farmers (90\%) on the other hand, said that they used to personally do the sorting, while $8.8 \%$ said that it was an activity for the mother and her children, another $2.2 \%$ either said it was the husband or hired labor respectively. There were no major changes in sorting after the far- 
mers started using mobile phones and radios for agricultural production, except, a reduction from $90 \%$ to $83.3 \%$ among women farmers who personally did the sorting.

\subsubsection{Drying}

A majority of the 32 men farmers (65.6\%) said that drying was mainly a joint activity before the use of mobile phones and radios in agricultural production, followed by $18.8 \%$ who said that it was their wives who used to do this activity. The percentage of men farmers who said that they personally used to dry their produce was $15.6 \%$. On the other hand, a majority of the 89 women farmers $(68.6 \%)$ said that they were drying the produce themselves, followed by $22.5 \%$ who said that it was a joint activity by the husband, wife, and children. Children as a category contributed $7.9 \%$ to the drying of produce of the women farmers and hired labor constituted $3.4 \%$ of the same. After the use of mobile phones and radios, the study revealed a six percent increase among the men farmers who were drying produce, from $15.6 \%$ to $21.5 \%$. The findings also showed a slight reduction among the women farmers who used to dry produce by themselves, from $68.6 \%$ to $62.5 \%$.

\subsubsection{Storage}

The biggest percentage of the 32 men farmers (59.4\%) said that the storage of produce was a joint activity for husbands, wives, and children before the use of mobile phones and radios, followed by $25.1 \%$ who said that they personally used to store the produce. A further $15.6 \%$ said that it was a wife's duty to store produce. On the other hand, a majority of the 90 women farmers $(61.1 \%)$ said that storage was their personal activity, followed by $22.2 \%$ that said it was a joint activity between the husband, wife, and children, while $14.4 \%$ said that it was the husband's duty. After the use of mobile phones and radios, out of the 32 men respondents, $30.3 \%$ said that they themselves participated in storage, a five percent increase. However, findings also showed a five percent reduction among men farmers that had reported storage as a joint activity for household members from $59.4 \%$ to $54.6 \%$. Negligible changes were noted for women farmers among the labor provision for storage after they started using mobile phones and radios for agricultural production.

\subsubsection{Transportation of Produce to the Market}

Half of the 30 men farmers who responded to this question said that they had been transporting agricultural produce to the market before they started using mobile phones and radios. A further $33.3 \%$ said that transportation was a joint effort between the husband, wife, and children, while traders and hired labor contributed in $3.3 \%$ of the cases. Of the 84 women farmers who responded to this question, $38.1 \%$ said that their husbands transported the produce to the market before they started using mobile phones and radios. A further $25 \%$ said that they were personally transporting the produce, while $23.8 \%$ said it was joint efforts between the husband, wife, and the children. Interestingly, boys as an in- 
dependent category contributed $8.3 \%$ to the transportation of women farmers' produce to the market, while hired labor contributed $4.8 \%$ of the same. After they started using mobile phones and radios, the personal labor contribution of 29 men farmers reduced from $50 \%$ to $37.9 \%$, a drop of $12 \%$. However, findings showed an eight percent increase among the men farmers who said that they were using joint efforts of husband, wife, and children to transport produce, from $33.3 \%$ to $41.3 \%$. On the part of the 82 women farmers who attempted this question, there was a $14 \%$ reduction among women farmers who were reliant on their husbands' contribution in transportation, from $38.1 \%$ to $24.4 \%$. Findings also showed an $11 \%$ spike among women farmers, who said that transportation of produce to the market was now a joint effort, from $23.4 \%$ to $34.3 \%$.

Findings also revealed that $33.3 \%$ of the men farmers the 30 men respondents, and $37.1 \%$ the 89 women respondents, were selling from home before mobile phones and radios for agricultural production were introduced. This was followed by $23.4 \%$ of the men respondents who were selling their produce at distances over $6 \mathrm{~km}$, while the second highest number of women respondents (21.3\%), said that they were selling at less than a kilometer from home. A further $20 \%$ of the men farmers were selling their produce at distances ranging between 3 - $6 \mathrm{kms}$, while the third highest percentage of women farmers (16.9\%), were selling their produce at the same distances. A share of the male farmers (13.3\%) were selling their produce at less than a kilometer, while the fourth highest percentage of women farmers (14.6\%), were selling their produce at more than 6 kms. The smallest percentages of both men (10\%) and women farmers (10.1\%) were selling their produce at distances ranging between $1-3 \mathrm{kms}$. After mobile phones and radios were introduced, there was a $34 \%$ increase in the number of men farmers selling from home, from $33.3 \%$ to $67.7 \%$, while women farmers selling from home increased by $23 \%$, from $37.1 \%$ to $55.7 \%$. This change was attributed to the fact that farmers could now sell from their homes by simply calling the traders, agreeing on the price of the produce and they would come and pick it.

\subsubsection{Marketing}

A majority of the 33 men farmers (65.7\%) who responded to this question said that they were personally doing the marketing of produce before the use of mobile phones and radios in agricultural production. A further $37.1 \%$ said that it was a joint effort between the husband and the wife. The involvement of children as a category was not visible. Out of the 88 women farmers, findings showed that $38.6 \%$ relied on their husbands to market the produce before the use of mobile phones and radios, followed by $37.5 \%$ who said that they personally did the marketing. A further $18.1 \%$ said that marketing had been a joint effort of the husband, wife, and children, while $4.5 \%$ said that it was the boys doing the marketing. After the use of mobile phones and radios, the percentage of men farmers doing marketing dropped by nearly $10 \%$, to $54 \%$, as well as that of those saying that it was joint efforts of the husband, wife and children, from $37.1 \%$, to $33.4 \%$. 
For the first time, three percent of the men farmers mentioned that their young sons did the marketing for them. A further $6.1 \%$ said that their wives did the marketing for them, which was unlike before. On their part, the number of women farmers who were reliant on their husbands had reduced by $11 \%$, from $38.6 \%$ to $27.3 \%$. Findings also showed a nine percent increase among women farmers who attributed marketing to joint efforts of the husband, wife, and children, from $18.1 \%$ to $27.3 \%$.

Farmer group marketing was the other medium of marketing produce. Group members would harvest and collect their produce at a central place for joint marketing. This type of marketing earned the farmers more money since they could negotiate better as a group, because of the quantities of the produce they were selling. It is the same method used to market produce from the farmer group gardens.

Agricultural information has empowered us, especially the market information. These days, we wait and sell our produce at once and in bulk as group members unlike those days. We are now even getting better payments for our produce and as you can see here; this lady [owner of the home where the discussion was taking place] has even built her house. You will also see at least a bicycle in every household. ( Women FGD, Oribcan women farmers' group, March 2018.)

Qualitative interviews revealed that farmer group members also doubled as produce buyers out of the exposure they had accumulated. A female group member of Oribcan women farmer group, described as a strong woman by one of her friends who were also a produce buyer, was one of several group members who were produce buyers as well. She would buy cereals from farmers, including her group members, resell some of it to them, but also sell to other buyers in Apac and in surrounding schools. This woman had picked skills of sorting good grains from the radios programmes, and buyers only buy good grains. The grains had to be treated before storage and dried properly before packing them. Wet grains were said not to last long and weighed more than properly dried ones. This knowledge had kept her in business for many years. Another male group member from the same farmer group also said that he buys produce from the community as well as fellow group farmers, though, his was a smaller scale compared to the female trader referred to above.

\subsubsection{Preparation of Seed for Planting Season}

An important aspect of the qualitative information emerged when we visited Ibabang Kwo women farmers group for an FGD. On arrival, we observed that several women farmers were preparing groundnuts' seed for planting. They were shelling the groundnuts from the store. Our team gladly joined in the activity but when one of the men group members joined us, he sat on his chair and looked on with no inclination to join in the activity. On enquiry, it emerged that actually this was mainly a women's activity. Women prepared seeds for the next season. This included storage of the seeds, and other activities such as shelling 
the seeds from the pods. When we probed the lone man, he jokingly said that he was too tired and would thus keep helping with chasing the hens away from the shelled groundnuts. Men hardly participated in the activity.

\section{Gender Roles in Crop Production: A Discussion}

The study findings revealed interesting points of discussion about gender roles in crop production after farmers started using mobile phones and radios. For many crop production processes, there is no meeting point for what men and women farmers cite as changes. What is obvious, however, is the fact that changes occurred over the spectrum of crop production activities once the farmers accessed and used mobile phones and radios. Many of the activities undertaken on the farms like land clearance, sowing, and harvesting among others, tended to become more egalitarian with the dominance of either men's or women's labor diminishing once the technologies got in use.

Clearance of farm land had been a masculine activity for most of the men and women farmers, which had drastically changed to a more joint activity where the husband, wife and children provided more labor and also the use of hired labor had increased. While the men still dominate, their labor share to the activity had dwindled as revealed by the study. This finding challenges the assertions by some studies [6], [49] that men dominate in land clearance because of their physical strength. Because land in Apac district is mainly covered by short grass with shrubs that should be easier to clear by all, including women and children, as seen in this study. Our study in a way moves closer to a study done among Indian communities that found out that land clearing and preparation is a feminine role with little input from men [7]. The role was increasingly in-between masculine and feminine arguments. No wonder, with increases in incomes, both men and women farmers could now afford to hire labor to do this previously masculine activity.

The study revealed that the prowess of masculinity in acquisition of agricultural information had waned in favor of a joint approach that brings the wife, husband and children on board, in most cases, thanks to technology use. This not only infers more bargaining in household agricultural information acquisition but also challenges the assertion of men as having more contact with government extension workers [20]. However, for acquisition of agricultural inputs, the activity remained masculine on the men farmers' side, while more women farmers reported an increase in their own ability to personally access information on agricultural inputs from radios or through a mobile phone. The changes on the women farmers' side created more independent women farmers on one hand, and those whose ability to engage in decision-making through a joint approach on the other, saw a diminished role for husbands in the access to agricultural inputs. Unlike the near single approach on the men farmers' side, women farmers are multi-pronged and flexed their empowerment by accessing the information alone or jointly with other household members. 
When it comes to sowing, the study revealed that this was an activity in which joint efforts between the husband, wife and children mainly faced competition from feminine tendencies for both men and women farmers. Contrary to other communities where sowing is actually a male activity [7], in Apac, women farmers' personal participation in sowing radically increased as that of the men farmers collapsed into more equality. When it came to weeding, the activity moved more to gender equality with both men and women farmers moving to joint weeding labor, compared to the period before they started using mobile phones and radios. There was also an increase in the number of men and women farmers that had resorted to hiring labor to weed their crops.

Harvesting was revealed as a historically more gender equal activity for both men and women farmers. There was however an increase in the number of men and women farmers that got involved in harvesting when mobile phones and radios were introduced, and children too started chipping in. It is also obvious that there was more produce to harvest after mobile phones and radios were introduced, and the quicker harvesting was done, the better. In most of the literature, harvesting is amore joint activity for household members than other activities [5] [6] [7]. Whereas not to the depth of harvesting, transportation from the garden to the home was a more joint affair between the husband, wife and children with some hired labor, especially among the men farmers.

According to the findings, the most feminine activity in the entire crop production value chain was sorting. Whether before or after the use of mobile phones and radios, this was dominated by women with very minimal involvement of the men. Crops like maize, peas, millet, sorghum, sim sim, beans and sunflower require sorting, implying that this feminized home-based activity demands a lot from women's labor and time during harvesting time. This is the same scenario in agrarian India [6] [7]. With increased productivity, more pressure is heaped on the women to quickly deliver these crops for home consumption, as well as for the market. There was no evidence that this lopsided labor provision had been breached by the use of technology in agricultural production. In fact, as technology domesticates previously public roles like marketing, even as women join the activity, they remain at home, making it easier for them to be more susceptible to home-based activities like sorting.

The study also revealed interesting gender tendencies about the drying of produce. Our findings showed that increasingly, men farmers were convinced that it indeed was a more joint activity between the husband, wife and children, while women farmers on the other hand projected drying as a feminine activity before and after the use of mobile phones and radios with little input from the husband or the children. The lack of agreement on this particular activity is interesting as it gives two dominant perspectives from both men and women farmers with no semblance of a meeting point. One study [8] had attributed post-harvest handling activities to women, which is not clear cut in this case as there is no agreement on who performs the activity depending on whether you 
talk to a man or a woman. Either way, women broadly offered more labor to drying than men farmers did, whether through joint labor or as women.

Like was the case for drying, storage elicited very divergent gender responses, with men farmers saying that it is a joint activity in which their own personal involvement had slightly increased after they started using mobile phones and radios, while the women farmers identify with it as a feminine activity. The implication is that women offer more labor than other household members, either individually or alongside their husbands. Storage is a powerful stage in the production process as it is the gateway to the next season's seeds, as well as safe custody for whatever sereal is to be sold by a farmer. One study [6] found that women were in charge of seeds for the next planting season, while another [8] attributed post-harvest handling activities to women. This alludes to the kind of power women hold at this level of crop production where one can determine the amount of seeds to keep or sell if need arises.

Transportation of produce to the market, hitherto a more masculine role before the use of mobile phones and radios, had become a more gender equal activity with more participation from wives alongside their husbands. This came at the cost of individualized men and women transportation arrangements before the use of the two technologies for agricultural information. Marketing of produce too revealed interesting gender realignment. Whereas the study reveals a masculine activity, especially from the men farmers' perspective, the huge reduction in their involvement points to a big change that is taking place at this stage of agricultural production. The $10 \%$ drop among women farmers who had been reliant on their husbands to do the marketing since mobile phones and radios were introduced is evidence that more women got empowered to do marketing by themselves. Marketing in the literature [8] [9], is portrayed as a male domain, though one study [5] indicated that women actually sell all the crops that they farm.

Throughout the different crop production activities, children as a broad category offer labor in the crop production process, but boys as a category stand out as an important source of labor to women farmers during transportation to the market, as well as in marketing itself. This points to a masculinised understanding of these two activities where mothers conveniently substitute a husband's labor input with that of the son. Both activities are more publicly oriented and eventually lead to interaction with people outside the home, as well as to income, confirming stereotypes of transportation of produce and marketing as masculine activities. On the other hand, winnowing which is a highly feminized activity attracts children's labor, but girls are directly mentioned as the labor providers alongside their mothers for this home-based activity. The role of children in agriculture, whether subsistence or market oriented, is understated in most literature as researchers' concentrate on gender roles of adults and omit the labor contribution of children.

The study revealed that hired labor was intermittently used in various crop production activities, more so in clearing of land, preparation of land, weeding, 
harvesting, sorting and transportation from the garden, except sorting. Only men farmers used hired labor for sorting because it is constructed as a feminine activity. As the productivity and income of the farmers increased, thanks to the use of mobile phones and radios, the need for more labor on the farm and the ability to pay for it increased. This eased the pressure on the labor demanded of both men and women farmers, as well as other household members, who in the absence of this extra labor, would have invested more time and energy into farming.

\section{Conclusions}

The study revealed that the access to and use of mobile phones and radios as sources of agricultural information empowered men and women to change gender roles in agricultural production. The change in roles is traced in the type of crops grown by men and women and then the roles they perform in the agricultural production process. Findings indicated that both men and women farmers were involved in the growth of all the crops, which serve as both cash crops and food crops. To move from food crops to cash crops is empowering for especially women farmers, as they can then command income and participate more in the household decision-making processes. The introduction of mobile phones and radios led to increased participation of men in the growing of sim sim, sweet potatoes and sunflower, while women's empowerment was more felt in their involvement in the growth of sunflower, beans, maize, sweet potatoes, sim sim and sorghum. The crops that are grown by the women serve a dual purpose as food crops and cash crops, for both household food security and economic empowerment.

In addition, empowerment was visible in the involvement of both men and women farmers in various crop production activities including land preparation, acquisition of agricultural information, acquisition of agricultural inputs, sowing, weeding, harvesting, transportation from the garden, winnowing, sorting, drying, storage, transportation to the market, marketing and preparation of seed for the next planting season. There was more joint labor provision from both men and women farmers except in winnowing, which was more of a feminine agricultural activity than all the other activities. The study revealed a visible shift in the agricultural production process, where men and women got more involved jointly in activities that were previously for either men or women alone.

\section{Declaration}

Findings used in this paper were extracted from a $\mathrm{PhD}$ study funded by the Swedish International Development Agency (SIDA).

\section{Conflicts of Interest}

The authors declare no conflicts of interest regarding the publication of this paper. 


\section{References}

[1] West, C. and Zimmerman, D.H. (2007) Doing Gender. In: Cook, N., Ed., Gender Relations in Global Perspective: Essential Readings, Canadian Scholars' Press Inc., Toronto.

[2] Dasgupta, I. (2000) Women's Employment, Intra-Household Bargaining and Distribution: A Two-Sector Analysis. Oxford Economic Papers, 52, 723-744. https://doi.org/10.1093/oep/52.4.723

[3] Green, A.H., Owen, D. and Dudleston, A. (1997) Who Decides What? Decision Making in Dual Career Households. Work, Employment and Society, 11, 313-326. https://doi.org/10.1177/0950017097112006

[4] Aase, T.H., Chaundhary, P.R. and Vetaas, R.O. (2010) Farming Flexibility and Food Security under Climate Uncertainity: Manang, Nepal Himalaya. Area, 42, 228-238. https://doi.org/10.1111/j.1475-4762.2009.00911.x

[5] Osterud, G. (1999) The Intellectual Legacy of Mary Neth's Work on Farm Women and Rural Communities. Agricultural History, 83, 430-436. https://doi.org/10.3098/ah.2009.83.4.430

[6] Roth, J.B. (2006) The Role of Gender in the Adoption of Agriculture in the Southwest. Journal of Anthropological Research, 62, 513-538. https://doi.org/10.3998/jar.0521004.0062.404

[7] Choundray, N. and Parthasarathy, D. (2007) Gender, Work and Household Food Security. Economic and Political Weekly, 42, 523-531.

[8] Hillenbrand, E. (2010) Transforming Gender in Homestead Food Production. Gender and Development, 18, 411-425. https://doi.org/10.1080/13552074.2010.521987

[9] Sorensen, P. (1996) Commercialisation of Food Crops in Busoga, Ugand and the Renegotiation of Gender. Gender and Society, 10, 608-628. https://doi.org/10.1177/089124396010005007

[10] Doss, R.C. (2001) Designing Agricultural Technology for African Women Framers: Lessons from 25 Years of Experience. World Development, 29, 2075-2092. https://doi.org/10.1016/S0305-750X(01)00088-2

[11] Lee, J., Martin, A., Kristjanson, P. and Wollenberg, E. (2015) Implications on Equity in Agricultural Carbon Market Projects: A Gendered Analysis of Access, Decision Making and Outcomes. Environment and Planning A, 47, 2080-2096. https://doi.org/10.1177/0308518X15595897

[12] Urquieta, N.R. and Alwang, J. (2012) Women Rule: Potato Markets, Cellullar Phones and Access to Information in Bolivian Highlands. International Association of Agricultural Economics, 43, 405-415. https://doi.org/10.1111/j.1574-0862.2012.00592.x

[13] Porter, G. (2012) Mobile Phones, Livelihoods and the Poor in Sub-Saharan Africa: Review and Prospects. Geography Compass, 6, 241-259. https://doi.org/10.1111/j.1749-8198.2012.00484.x

[14] Ogbeide, O.A. and Ele, I. (2015) Smallholder Farmers and Mobile Phone Technology in Sub-Saharan Agriculture. Mayfair Journal of Information Technology Management in Agriculture, 1, 1-19.

[15] Gakuru, M., Winters, K. and Stepman, F. (2009) Innovative Farmer Advisory Services Using ICT. IST-Africa 2009 Conference Proceedings, IST-Africa, Nairobi, 6-8 May 2009. http://www.ist-africa.org/conference2009 
[16] Republic of Uganda (2015) Second National Development Plan (NDPII) 2015/2016-2019/2020. Uganda National Planning Authority, Kampala.

[17] Republic of Uganda (2016) The National Population and Housing Census 2014: Main Report. Uganda Bureau of Statistics (UBOS), Kampala.

[18] USAID (2012) Briefing Paper. USAID, Washington DC.

[19] Wamala, C. (2010) Does IT Count? Complexities between Access to and Use of Information Technologies among Uganda's Farmers. Dissertation, Lulea University of Technology.

[20] Afranaakwapong, N. and Nkonya, E. (2015) Agricultural Extension Reforms and Development in Uganda. Journal of Agricultural Extension and Rural Development, 7, $122-134$.

[21] Masika, R. and Bailur, S. (2015) Negotiating Women's Agency through ICTS: A Comparative Study of Uganda and India. Gender, Technology and Development: Asian Institute of Technology, 19, 43-69.

[22] Omondi, I., Kihara, A. and Baltenweck, I. (2016) East African Farmers to Benefit from Using Mobile Phones to Record Yields. ILRI Research Brief 58.

[23] Komunte, M. (2015) Usage of Mobile Technology in Women Entreprenuers: A Case Study of Uganda. The African Journal of Information Systems, 7, 51-74.

[24] Mpiima, M.D. (2014) Access to Agricultural Information: Changing Gender Roles and Decision Making Patterns in Nakaseke District, Uganda. In: Kyomuhendo, G.B., Muhanguzi, F.K. and Gerrard, S., Eds., Ahikire and Josephine, Gender, Poverty and Social Transformation: Reflections on Fractures and Continuities in Contemporary Uganda, Fountain Publishers, Kampala, 139-168.

[25] Manyire, H. and Apekey, A.D. (2013) Mainstreaming Gender Equality in African Agricultural Research and Development: A Study of Constraints and Opportunities. Forum for Agricultural Research in Africa (FARA), Accra.

[26] Asingwire, N. and Okello, J.J. (2011) Challenges Facing Smallholder Farmers' ICT-Based Market Information Services (MIS) Projects: The Case of BROSDI and WOUGNET in Uganda. International Journal of Economic Resources, 2, 142-152.

[27] Anderson, G. and Elliott, D. (2007) The Role and Impact of Radios in Reforming the Rural Business Environment in Africa: A Study of Private FM Radios in Uganda. Creating Better Business Environments for Enterprise Development: Africa and Global Lessons for More Effective Donor Practices.

[28] Ebanyat, P., Ridder, D.N., Jager, D.A., Delve, J.R., Bakunda, A.M. and Giller, E.K. (2010) Drivers of Land Use Change and Household Determinants of Sustainability in Smallholder Farming Systems in Eastern Uganda. Population and Environment, 31, 474-506. https://doi.org/10.1007/s11111-010-0104-2

[29] Curley, R. (1973) The Lango of North Central Uganda. In: Molnos, A., Ed., Beliefs and Practices, East African Publishing House, Nairobi, 299-317.

[30] LANDac (2016) Food Security and Land Governance Factsheet Uganda. Netherlands Academy on Land Governance for Equitable and Sustainable Development.

[31] Lehrer, K. (2009) Gender Differences in Labour Market Participation during Conflict: Evidence from Displaced People's Camps in Northern Uganda.

[32] Agong, R.B. (2008) Exclusion or Inclusion? Where Do We Stand? Impacts of HIV/AIDS on Participation of HIV/AIDS Affected Households in Group Labour Exchange Activities: The Case of Uganda Oil Seed Producers and Processors Association (UOSPA). Unpublished Dissertation, Vanhall Larenstein University of Applied Sciences. 
[33] Ebong-Opyene, J. (1996) Forms of Peasant Agricultural Co-Operatives in Uganda: A Case Study of Lango. Organisation for Social Science Research in Eastern and Southern Africa (OSSREA).

[34] Amone, C. (2014) The Values of Polygamy among the Langi People of Northern Uganda. Global Journal of Interdependence Social Sciences, 3, 48-52.

[35] Namuggala, V. and Mulumba, D. (2014) War Experiences and Gendered Responses to Post Conflict Reintegration: The Case of Lira District in Northern Uganda. In: Asuelime, L. and Francis, S., Eds., Selected Themes in African Political Studies. Advances in African Economic, Social and Political Development, International Publishing, Cham, 25-38.

[36] Auma, S. (2016) Land Conflict, Gender and Agricultural Production: A Case of Apac District, Northern Uganda. Dissertation, Norwegian University of Life Sciences, Ås.

[37] World Bank (2016) Uganda Poverty Assessment 2016: Farms, Cities and Good Fortune: Assessing Poverty Reduction in Uganda from 2006-2013. World Bank Group, Washington DC. https://doi.org/10.1596/26075

[38] Nicholl, H. (2007) The Gender Dimension of Communication Technologies in Uganda: Documenting ICTs in the Daily Lives of Women. Dissertation, Ryerson University, York University.

[39] Weih, U., Okoboi, G., Janowski, M., Omony, G., Taiwo, B. and Bisase, D. (2005) Synthesis of an Evaluation Survey in Seven Sub-Counties of Lira, Apac and Soroti Districts. Technical Report, Natural Resources Institute, Chatham.

[40] Kabeer, N. (2016) Voice and Agency: Where Are We Now? Feminist Economics, 22, 1-29. https://doi.org/10.1080/13545701.2015.1101308

[41] Cornwall, A. (2016) Women's Empowerment: What Works? Journal of International Development, 28, 342-359. https://doi.org/10.1002/jid.3210

[42] Eerdewijk, V.A., Wong, F., Vaast, C., Newton, J., Tyszler, M. and Pennington, A. (2017) White Paper: A Conceptual Model of Women and Girls' Empowerment. KIT Gener.

[43] Kabeer, N. (1999) The Conditions and Consequences of Choice: Reflections on Measurement of Women's Empowerment. United Nations Institute for Social Development Discussion Paper No. 108, Geneva.

[44] Uphoff, N. (2012) Analytical Considerations of "Power" as the Basis and Goal of "Empowerment". http://www.un.org/esa/socdev/egms/docs/2012/NormanUphoffPower.pdf

[45] Hanmer, L. and Klugman, J. (2016) Exploring Women's Agency and Empowerment in Developing Countries: Where Do We Stand? Feminist Economics, 22, 237-263. https://doi.org/10.1080/13545701.2015.1091087

[46] Kaur, S. (2010) Issue of Women's Empowerment in Punjab: A Critique. The Journal of Political Science, 71, 333-344.

[47] Sharma, L.S. (2000) Empowerment without Antagonism: A Case for Reformation of Women's Empowerment Approach. Sociological Bulletin, 49, 19-39. https://doi.org/10.1177/0038022920000102

[48] Alsop, R. and Heinsohn, N. (2005) Measuring Empowerment in Practice: Structuring Analysis and Framing Indicators. Word Bank Policy Research Working Paper 3510. https://doi.org/10.1596/1813-9450-3510

[49] Cornwall, A. and Edwards, J. (2010) Introduction: Negotiating Empowerment. IDS Bulletin, 41, 1-9. https://doi.org/10.1111/j.1759-5436.2010.00117.x 